RESEARCH ARTICLE

\title{
Studies on Seed Dormancy and Breaking Methods in Groundnut cv.VRI 7
}

\author{
Shobha $\mathrm{KV}^{{ }^{*}}$, Renugadevi $\mathrm{J}^{1}$ and Jerlin $\mathbf{R}^{1}$ \\ 1*Department of Seed Science and Technology, Tamil Nadu Agricultural University, Coimbatore-641 003.
}

Received : $26^{\text {th }}$ May, 2020

Revised : $08^{\text {th }}$ June, 2020

Accepted : $23^{\text {rd }}$ June, 2020

\begin{abstract}
The semispreading groundnut variety VRI 7, a hybrid derivative was used to study the dormancy status and breaking methods. The cultivar VRI 7 exhibited dormancy for a duration of 30 days. The fresh kernels were subjected to various dormancy breaking treatments viz., warm stratification, cold stratification, seed treatment with $\mathrm{GA}_{3}$, ethrel and theircombinations. Among different dormancy breaking treatments, groundnut kernels subjected to warm stratification was evaluated as the effective treatment for breaking dormancy and enhanced the seed germination and vigour.
\end{abstract}

Keywords: Dormancy; Groundnut; ethrel; $G A_{3}$; warm stratification and cold stratification

\section{INTRODUCTION}

Groundnut (Arachis hypogaea L) is the most important oilseed and cash crop in semi-arid tropics. Taxonomically, the cultivated peanut $A$. hypogaea $\mathrm{L}$. is divided into two subspecies, one with two botanical varieties, and another with four. In the subspecies hypogaea var. hypogaea (Virginia and Runnermarket types) and var. hirsuta, have long duration cycle and dormant seeds. While in subspecies fastigiata with var. fastigiata (Valencia market class) and var. vulgaris (Spanish market class), are early maturing but generally withoutfresh seed dormancy. Attempts to (Krapovickas, 1994) select peanut lines from inter subspecies Virginia X Spanish crosses may lead to lines with fresh seed dormancy but matures up to 10 days latter than the Spanish parent. Some authors found (Wadia, 1984) genetic variability within ssp. fastigiata for fresh seed dormancy.

In groundnut, seed dormancy has been reported to be controlled by two hormones: abscisic acid, which inhibits sprouting, and ethylene (Ketring etal.,1976), which isaccumulated instorageto break dormancy (Shibuya, 1993). Short period of seed dormancy is necessary to reduce losses. Hull (1937) found dormancy in peanut seeds to be a function of temperature, time and dormancy decreased as storage temperature increased from 30 to $40^{\circ} \mathrm{C}$. Many scientists reported that dormancy of variety Virginia Bunch 67 was broken 40 days after harvest if the pods were held at $30^{\circ} \mathrm{C}$ and in 15 days if they were held at $40^{\circ} \mathrm{C}$ and $50^{\circ} \mathrm{C}$. When pods remained on plants in the ground or in field stacks, the dormant condition persisted considerably longer than 40 days.

According to Bandyopadhyay et al. (1999) in groundnut seeds, dormancy is imposed due *Corresponding author's e-mail: shobhakvreddy@gmail.com to different parts like seed coat, cotyledons and embryonic axis. It is believed that thickness and impermeability of seed coat (testa) is one of the important causes of seed dormancy. The seed coat acts as a barrier for the exchange of gases and entry of water which are essential for initiation of germination process. Gulek et al. (1977) reported that there are significant morphological differences in the test a among various cultivars of groundnut which varied from thincompact test a tothickerones. Despite the importance of dormancy in groundnut production (Vaish et al., 1994), there has been few studies conducted on the inheritance of its fresh seed dormancy which creates problem to seed technologist to get a true prediction in standard germination test (Anonymous,1995).

The objectives of the study were in order (i) to find out the seed dormancy status (ii) to find out suitable methods to break seeddormancy.

\section{MATERIAL AND METHODS}

The cleaned pods were used for estimation of seed quality parameters for determining the status of seed dormancy. To break dormancy in dormant groundnut cv.VRI 7, the plants were raised in field at the Department of Seed Science and Technology, Tamil Nadu Agricultural University, Coimbatore and the freshly harvested pods were collected. Immediately after harvest, the pods were sun dried to accomplish a moisture content of 8 percent determining status of seed dormancy germination test was conducted till the sample registered $>70 \%$ germination which is the minimum standard germination for groundnut as per Indian Minimum Seed Certification Standards. 


\section{Treatment details}

To determine the status of seed dormancy, the dormant groundnut variety was subjected to the following seed treatments viz., seed treatment with ethrel (200 ppm for $6 \mathrm{~h}$ ), GA3 (500 ppm for $6 \mathrm{~h}$ ), cold stratification ( 0 to $5^{\circ} \mathrm{C}$ for 2 days), warm stratification ( $25^{\circ} \mathrm{C}$ temperature for 2 days) and combination of cold stratification and warm stratification with GA3 and ethrel. Seeds were soaked at seed to solution ratio of $(\mathrm{v} / \mathrm{v})$ 1:2. Seed treatments were compared along with untreated control seeds.

\section{Cold stratification}

Seeds were incubated at low temperature of $0-5^{\circ} \mathrm{C}$ over a moist substratum for 2 days.

\section{Warm stratification}

Seeds were incubated at high temperature of $25-40^{\circ} \mathrm{C}$ over a moist substratum for 2 days.

The following observations on physiological and biochemical parameters were recorded.

\section{Speed of emergence}

Four replicates of twenty five seeds each were utilized to test the speed of emergence of seeds from various treatments. The seeds showing radical protrusion were checked and counted everyday from third day of sowing until tenth day. From the number of seeds germinated on each day, the speed of germination was calculated using the following formula and the result was expressed in number (ISTA., 2011).

Speed of emergence $=\frac{\mathrm{x}_{1}}{\mathrm{Y}_{1}}+\frac{\mathrm{x}_{\mathrm{n}}-\mathrm{x}_{1}}{\mathrm{Y}_{\mathrm{n}}}+\frac{\mathrm{x}_{\mathrm{n}}\left(\mathrm{x}_{\mathrm{n}}-1\right)}{\mathrm{Y}_{\mathrm{n}}}$

X1 - Number of seeds germinated at first count

X2 - Number of seeds germinated at second count $\mathrm{Xn}$ - Percent germination on $\mathrm{n}^{\text {th }}$ day

Y1 - Number of days from sowing to first count

Y2 - Number of days from sowingto second count

$\mathrm{Yn}$ - Number of days from sowing to $\mathrm{n}^{\text {th }}$ count

\section{Germination (\%)}

Four replicates of 100 seed from each treatment were kept for germination at $25 \pm 1^{\circ} \mathrm{C}$ temperature and $95 \pm 3$ percent relative humidity for 10 days using the sand method. The germination percentage was expressed on the basis of normal seedlings as described in ISTA Rules (ISTA., 2011).

\section{Abnormal seedlings (\%)}

The abnormal seedlings observed in the germination test were counted and the mean expressed in percentage.

\section{Fresh ungerminated seed (\%)}

The germination test was conducted according to ISTA (2011) and at the time of evaluation, the seeds which do not produce seedlings however remain fresh at the end of the test period are classified as fresh ungerminated seeds, and the mean expressed as percentage.

\section{Root length (cm)}

From the standard germination test, ten normal seedlings were chosen at indiscriminately from every replication on $10^{\text {th }}$ day and the length of root was measured from the neckline region to the tip of the root to base of hypocotyl and the average root length was expressed in centimeter.

\section{Shoot length $(\mathrm{cm})$}

From standard germination test, ten normal seedlings were chosen at random from every replication on tenth day and the length of shoot was measured from the collar region to the tip of coleoptile and the average shoot length was expressed in centimeter.

\section{Dry matter production (g 10 seedlings-1)}

The seedlings utilized for measuring the seedling lengthafterexpelling cotyledons(remnantseed)were dried in hotair ovenat $80 \pm 1^{\circ} \mathrm{C}$ for 24 hoursand mean seedling dry weight was expressed in grams.

\section{Vigour index - I}

The germinated seedlings were assessed on 5th and 10th day as first and final count, respectively. The percentage of germination was expressed based on the normal seedlings present in the test. Ten normal and healthy seedlings from each replication were chosen randomly on $10^{\text {th }}$ day and seedling length (shoot and root) was measured in centimeter. Then the Seedling Vigour Index-I was determined by multiplying standard germination (\%) and mean seedling length $(\mathrm{cm})$ and expressed in number (Abdul-Baki and Anderson, 1973).

Vigour index $-\mathrm{I}=$ Germination (\%) $\times$ Mean seedling length $(\mathrm{cm})$

Vigour index - II

The seedlings selected for calculating the seedling vigour index-I were oven dried after removing the cotyledon (remnant seed) and the mean the mean seedling dry weight of these seedlings was used for calculating the seedling Vigour Index-II by using the formula given by Abdul Baki and Anderson (1973) as indicated below:

Vigour index II = Germination (\%) $x$ Mean seedling dry weight (g)

Electrical conductivity of seed leachate $\left(\mathrm{dSm}^{-1}\right)$ 
Four duplicates of twenty five seeds each were washed with distilled water to evacuate the dust particles and then soaked in $50 \mathrm{ml}$ of distilled water for $8 \mathrm{~h}$ at room temperature. After soaking, the seed soak water was emptied to obtain the seed leachate. The electrical conductivity of the seed leachate was estimated in a digital conductivity meter with a cell constant of one and expressed as $\mathrm{dSm}^{-1}$ (Presley, 1958).

\section{Statistic}

The experimental design used was a completely randomized design (CRD). Data were subjected to analysis of variance (ANOVA) using the OP STAT software.

\section{RESULTS AND DISCUSSION}

Freshly harvested seeds were collected and dried to safe moisture content and dormancy studies were conducted at five days intervals. The duration of dormancy at five days after sowing i.e. percentage of non germinated seeds at five days after (NGS5) was highly significant (Table 1). At 0 days after drying. VRI 7 registered miminum germination of 5 percent, with more number of fresh ungerminated seeds (95\%), and electrical conductivity was $0.0571 \mathrm{dSm}^{-1}$. Seed germination was progressively increased with days after harvest. At 30 days after harvest, germination above minimum seed certification standards (IMSCS) i.e. > $70 \%$ was recorded. VRI 7 had 30 days of dormancy (Table 1).

Table 1. Physiological parameters of freshly harvested groundnut seeds

\begin{tabular}{|c|c|c|c|c|}
\hline $\begin{array}{l}\text { Days after } \\
\text { drying }\end{array}$ & $\begin{array}{r}\text { Germination } \\
\text { (\%) }\end{array}$ & $\begin{array}{r}\text { Fresh ungerminated } \\
\text { seeds(\%) }\end{array}$ & $\begin{array}{r}\text { Abnormal } \\
\text { seedlings (\%) }\end{array}$ & $\begin{array}{r}\text { Electrical } \\
\text { conductivity }\left(\mathrm{dSm}^{-1}\right)\end{array}$ \\
\hline 0 & $\begin{array}{r}5 \\
(12.92)\end{array}$ & $\begin{array}{r}95 \\
(77.14)\end{array}$ & $\begin{array}{r}0 \\
(2.87)\end{array}$ & 0.0571 \\
\hline 5 & $\begin{array}{r}16 \\
(23.57)\end{array}$ & $\begin{array}{r}84 \\
(66.45)\end{array}$ & $\begin{array}{r}0 \\
(2.87)\end{array}$ & 0.0572 \\
\hline 10 & $\begin{array}{r}34 \\
(35.67)\end{array}$ & $\begin{array}{r}66 \\
(54.33)\end{array}$ & $\begin{array}{r}0 \\
(2.87)\end{array}$ & 0.0576 \\
\hline 15 & $\begin{array}{r}40 \\
(39.23)\end{array}$ & $\begin{array}{r}58 \\
(49.60)\end{array}$ & $\begin{array}{r}2 \\
(8.13)\end{array}$ & 0.0578 \\
\hline 20 & $\begin{array}{r}54 \\
(47.29)\end{array}$ & $\begin{array}{r}42 \\
(40.39)\end{array}$ & $\begin{array}{r}4 \\
(11.54)\end{array}$ & 0.0579 \\
\hline 25 & $\begin{array}{r}58 \\
(49.60)\end{array}$ & $\begin{array}{r}36 \\
(36.86)\end{array}$ & $\begin{array}{r}6 \\
(13.65)\end{array}$ & 0.0581 \\
\hline 30 & $\begin{array}{r}78 \\
(62.03)\end{array}$ & $\begin{array}{r}16 \\
(23.57)\end{array}$ & $\begin{array}{r}6 \\
(13.65)\end{array}$ & 0.0582 \\
\hline 35 & $\begin{array}{r}92 \\
(73.61)\end{array}$ & $\begin{array}{r}4 \\
(11.54)\end{array}$ & $\begin{array}{r}4 \\
(11.54)\end{array}$ & 0.0585 \\
\hline 40 & $\begin{array}{r}98 \\
(82.21)\end{array}$ & $\begin{array}{r}2 \\
(8.13)\end{array}$ & $\begin{array}{r}0 \\
(2.87)\end{array}$ & 0.0586 \\
\hline 45 & $\begin{array}{r}98 \\
(82.21)\end{array}$ & $\begin{array}{r}2 \\
(8.13)\end{array}$ & $\begin{array}{r}0 \\
(2.87)\end{array}$ & 0.0590 \\
\hline 50 & $\begin{array}{r}98 \\
(82.21)\end{array}$ & $\begin{array}{r}0 \\
(2.87)\end{array}$ & $\begin{array}{r}2 \\
(8.13)\end{array}$ & 0.0595 \\
\hline 55 & $\begin{array}{r}100 \\
(87.13)\end{array}$ & $\begin{array}{r}0 \\
(2.87)\end{array}$ & $\begin{array}{r}0 \\
(2.87)\end{array}$ & 0.0597 \\
\hline 60 & $\begin{array}{r}100 \\
(87.13)\end{array}$ & $\begin{array}{r}0 \\
(2.87)\end{array}$ & $\begin{array}{r}0 \\
(2.87)\end{array}$ & 0.0599 \\
\hline SE.d ( ) & 1.156 & 0.497 & 0.047 & 0.0005 \\
\hline $\begin{array}{l}C D \\
(P=0.05)\end{array}$ & 2.313 & 0.995 & 0.094 & 0.0010 \\
\hline
\end{tabular}

These results were consistent with the findings of many authors. Pandya and Patel (1986) and Wadia et al. (1987). In fact, theyargued that there's genetic variability for seed dormancy among Spanish-type peanut varieties.

Baskin and Baskin (1998) have put forward five dormancy classes as part of a detailed system used to classify seed dormancy as follows: Physiological dormancy (PD), morphological dormancy (MD), physical dormancy (PY), morphophysiological dormancy (MPD), and combinational dormancy (CD).
Moreover, they have further subdivided dormancy classes into levels and types where appropriate. Endogenous, as well as exogenous parameters, may assist in maintaining or releasing dormancy, butthe embryonic morphology, water permeability of the seed coat, and germinating ability among fresh seeds within one month of reaching maturity are the keys to feasibly determining the dormancy state.

The primary disadvantage of seeds with dormancy is that, they cannot be utilized immediately after harvest for seed purpose. At the point when the fresh 
seeds are utilized for production of different class of seeds significant loss of seed material occur which hamper seed production programme specifically and crop performance in general (Elizabeth Farnsworth, 2000). To break the dormancy, the groundnut cultivar VRI 7 was subjected to various dormancy breaking treatments. Seed dormancy breaking treatments were found to have significant variations on seed germination and other seed quality parameters (Table 2). Germination reached above the IMSCS due to imposed seed treatments (T4 -Warm Stratification $\left(25^{\circ} \mathrm{C}\right.$ temperature for 2 days) (96\%), T7 (T4 + Ethrel @ 200 ppm for 6 hours) (94\%), T5 (Cold Stratification (0 to $\left.5^{\circ} \mathrm{C}\right)+$ Ethrel @ 200 ppm for 6 hours)) (92 \%) and T1 (Ethrel @ 200 ppm for 6 hours) (88\%).

Table 2. Effect of dormancy breaking treatments on physiological parameters in groundnut seeds

\begin{tabular}{|c|c|c|c|c|c|c|c|c|c|}
\hline Treatments & $\begin{array}{c}\text { Germination } \\
\text { (\%) }\end{array}$ & $\begin{array}{c}\text { Fresh } \\
\text { ungerminated } \\
\text { seeds (\%) }\end{array}$ & $\begin{array}{c}\text { Abnormal } \\
\text { seedlings (\%) }\end{array}$ & $\begin{array}{l}\text { Speed of } \\
\text { emergence }\end{array}$ & $\begin{array}{l}\text { Shoot } \\
\text { length } \\
(\mathrm{cm})\end{array}$ & $\begin{array}{l}\text { Root length } \\
\text { (cm) }\end{array}$ & $\begin{array}{l}\text { Seedling dry } \\
\text { weight }(10 \\
\left.\text { seedlings }^{-1}\right)\end{array}$ & $\begin{array}{l}\text { Vigour } \\
\text { index I }\end{array}$ & $\begin{array}{l}\text { Vigour } \\
\text { index II }\end{array}$ \\
\hline$T_{0}$ & 18 & 82 & 0 & 3.2 & 13.54 & 8.62 & 1.8 & 398 & 32 \\
\hline $\mathrm{T}_{1}$ & 88 & 2 & 10 & 6.2 & 16.97 & 11.42 & 2.4 & 2498 & 211 \\
\hline $\mathrm{T}_{2}$ & 48 & 40 & 12 & 3.5 & 15.3 & 9.51 & 2 & 1191 & 96 \\
\hline $\mathrm{T}_{3}$ & 40 & 48 & 12 & 3.4 & 15.34 & 9.80 & 1.9 & 1006 & 76 \\
\hline $\mathrm{T}_{4}$ & 96 & 0 & 6 & 6.3 & 17.32 & 13.05 & 2.5 & 2916 & 240 \\
\hline$T_{5}$ & 92 & 0 & 8 & 6.1 & 17.25 & 12.83 & 2.2 & 2767 & 202 \\
\hline$T_{6}$ & 28 & 62 & 10 & 3.2 & 15.17 & 11.23 & 2.1 & 792 & 63 \\
\hline $\mathrm{T}_{7}$ & 94 & 2 & 4 & 6.3 & 17.73 & 12.87 & 2.4 & 2876 & 226 \\
\hline $\mathrm{T}_{8}$ & 34 & 54 & 12 & 3.4 & 15.77 & 9.91 & 2.1 & 873 & 71 \\
\hline SE.d ( ) & 0.714 & 0.268 & 0.097 & 0.077 & 0.255 & 0.150 & 0.030 & 15.533 & 1.130 \\
\hline$C D(P=0.05)$ & 1.429 & 0.536 & 0.195 & 0.154 & 0.51 & 0.30 & 0.061 & 31.066 & 2.261 \\
\hline
\end{tabular}

$\mathrm{T}_{0}$ - Control $\mathrm{T}_{1}-$ Ethrel @ 200 ppm for 6 hrs. $\mathrm{T}_{2}-\mathrm{GA}_{3} @ 500$ ppm for 6 hrs. $\mathrm{T}_{3}-$ Cold stratification

$\mathrm{T}_{4}$ - Warm stratification $\mathrm{T}_{5}-\mathrm{T}_{3}+\mathrm{T}_{1} \quad \mathrm{~T}_{6}-\mathrm{T}_{3}+\mathrm{T}_{2} \quad \mathrm{~T}_{7}-\mathrm{T}_{4}+\mathrm{T}_{1} \quad \mathrm{~T}_{8}-\mathrm{T}_{4}+\mathrm{T}_{2}$

Joshi et al. (1980) found that germination increased when dormant seeds were pre-soaking in water. This study demonstrated that the relative amount of inhibitors and promoters in the seed coat would regulate the dormancy in groundnuts. The treatments T2 (GA3 @ 200 ppm for 6 hours) (48 $\%)$, T3 (Cold Stratification (0 to $5^{\circ} \mathrm{C}$ for 2 days)) (40 $\%)$, T6 (Cold Stratification (0 to $5^{\circ} \mathrm{C}$ for 2 days) +

GA3 @ 200 ppm for 6 hours)) (28\%) and T8 (Warm Stratification $\left(25^{\circ} \mathrm{C}\right.$ temperature for 2 days $)+$ GA3 @ 200 ppm for 6 hours)) (34 \%) were not effective in breaking seed dormancy and recorded very low germination and untreated seed recorded 18 percent germination. Ketring and Morgan (1971) studied the effect of ethephon on germination of groundnut seeds.

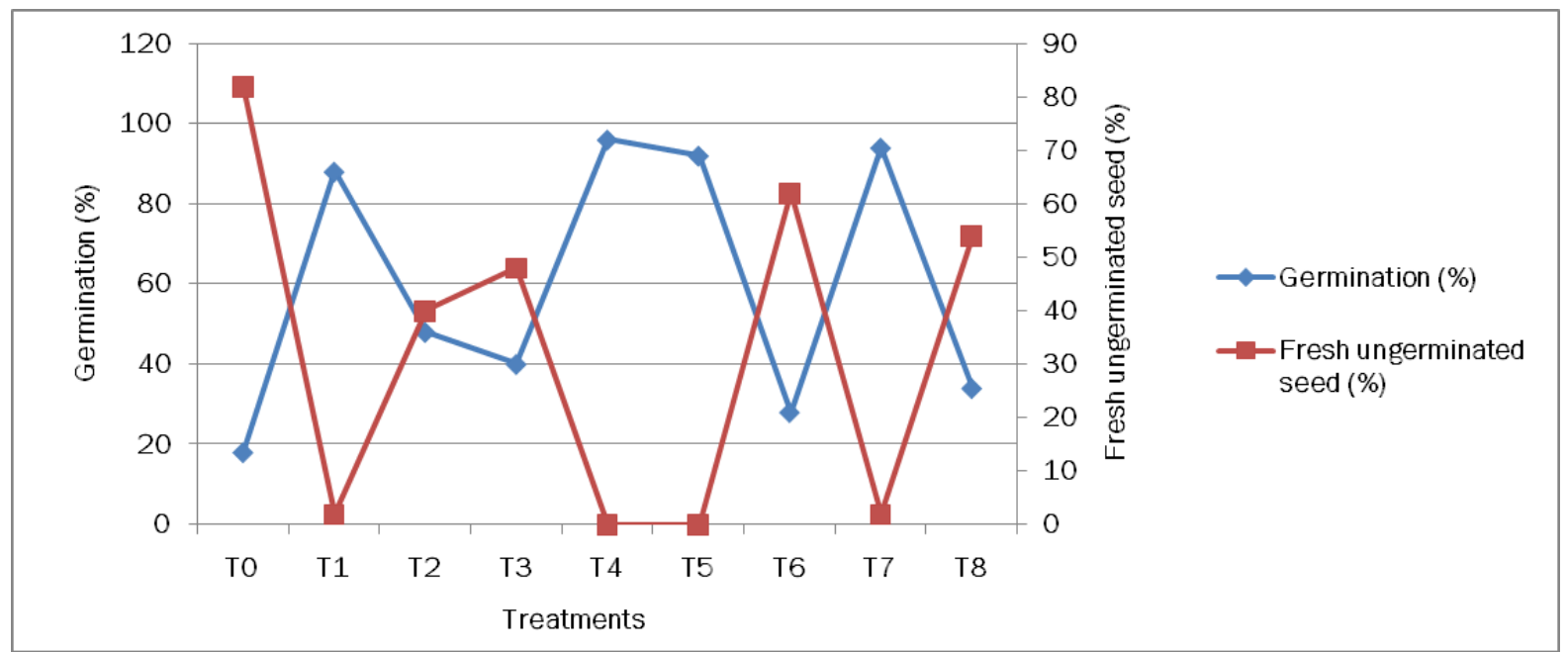

$T_{0}$ - Control $T_{1}$ - Ethrel @ 200 ppm for 6 hrs. $T_{2}-G_{3} @ 500$ ppm for 6 hrs. $T_{3}-$ Cold stratification

\section{Figure 1. Effect of dormancy breaking treatments on germination (\%) and fresh ungerminated seed in groundnut seeds}

Their observations revealed that ethephon treatment increased germination of the dormant seeds to a larger extent than that of the less dormant apical seeds. Ketring et al., (1976) studied the germination of NC -13 Virginia type groundnut seeds in the presence of inhibitors and ethylene. He noticed that when imbibed in cyclohexanide -6-methyl-purene or 6-azauracil (protein and nucleic 
acid synthesis inhibitor) seeds failed to germinate even after ethylene treatment. However, there was hundred percent germination in water imbibed seeds after ethylene treatment. The liquid substance Ethrel or Ethephon, which breaks down to ethylene, phosphonate and chloride (16), was found to break dormancy of peanut (Takayanagi et al., 1971). Exogenous ethrel overcome the inhibitory effects of ABA on germination of dormant peanut seeds (Ketring and Morgan, 1970). Ethrel also interact with light or gibberellin to promote germination at high temperature.

The fresh ungerminated seeds were minimum in seed treated with $\mathrm{T}_{4}$ (Warm Stratification $\left(25^{\circ} \mathrm{C}\right.$ temperature for 2 days) and $T_{5}$ (Cold Stratification (0 to $\left.5^{\circ} \mathrm{C}\right)+$ Ethrel @ 200 ppm for 6 hours)) followed by $T_{1}$ (Ethrel @ 200 ppm for 6 hours) and T7(Warm Stratification $\left(25^{\circ} \mathrm{C}\right.$ temperature for 2 days $)+$ Ethrel @ 200 ppm for 6 hours)) (Figure 1.). The maximum fresh ungerminated seeds were seen in control (82\%) followed by T6 (62\%). The speed of emergence was the highest in $\mathrm{T}_{4}$ (Warm Stratification $\left(25^{\circ} \mathrm{C}\right.$ temperature for 2 days) and $\mathrm{T}_{7}$ (Warm Stratification $\left(25^{\circ} \mathrm{C}\right.$ temperature for 2 days $)+$ Ethrel @ 200 ppm for 6hours))followed by $T_{1}$ (SeedtreatmentwithEthrel 200 ppm for 6 hours) while minimum speed was in $\mathrm{T}_{6}$ and control. The seedling length, seedling dry weight and vigour index were maximum in $\mathrm{T}_{4}$ (Warm stratification $\left(25^{\circ} \mathrm{C}\right.$ temperature for 2 days) followed by $\mathrm{T}_{7}$ (Warm Stratification $\left(25^{\circ} \mathrm{C}\right.$ temperature for 2 days)+Ethrel @ 200 ppm for 6 hours)) whereas minimum in control. (Tang et al., 2019) reported that warm stratification increased seed germination percentages of Sorbus alnifolia. They studied that one month of warm stratification plus cold stratification is superior to cold stratification alone with no previous warm treatment. Because seeds of some Sorbus species are also associated with a mechanical dormancy as a result of a hard seed coat(Tang etal., 2019), warm stratification can contributeto breaking down this hard seed coat. Thus, a short warm stratification before cold stratification was proposed to increase the germination percentage of Sorbus alnifolia seeds.

\section{CONCLUSION}

In conclusion, according to the results of this experiment, physiological dormancy in groundnut seeds were broken by warm stratification $\left(25^{\circ} \mathrm{C}\right.$ for 2 days) along with ethrel @ 200 ppm for 6 hours and significantly increases germination percentage of groundnut seeds.

\section{REFERENCES}

Abdul-Baki, A. Aref and J.D. Anderson. 1973. "Vigor determination in soybean seed by multiple criteria 1". Crop Sci., 13(6): 630-633.

Anonymous, 1995. Studies on seed dormancy. Annual Report, National Research Centre for Groundnut, Junagarh- 362 001, Gujarat, India.
Bandyopadhyay, A., Nautiyal, P.C., Radhakrishnan, T. and Gor, H. K. 1999. J. Agron. Crop Sci., 25: 37-41.

Baskin, C. C. and Baskin, J. M. 1998. Seeds, ecology, biogeography, and evolution of dormancy and germination. Academic Press, San Diego.

Elizabeth Farnsworth. 2000. The ecology and physiology of viviparous and recalcitrant seeds. Annual review of ecology and systematics., 31(1):107-138.

Gulek, James A., L. E. Clark and O. D. Smith. 1977. "Testa comparisons of four peanut cultivars 1." Crop Sci., 17: 777-782.

HULL, F. H. 1937. Inheritance of rest period of seeds and certain other characters in the peanut. Florida Agr. Expt. Sta. Tech. Bull. 314: 1-46.

ISTA. 2011. International Rules for Seed Testing. Bassersdorf, Switzerland: International Seed Testing Association.

Joshi, Geeta, S. S. Phartyal, and A. N. Arunkumar. 1980. "Non-deep physiological dormancy, desiccation and low-temperature sensitivity in seeds of Garcinia gummi-gutta (Clusiaceae): A tropical evergreen recalcitrant species." Tropical Ecol., 58:241-250.

Kentring, D. L., Benedict, C. RM. and Yeger. 1976. Growing season and location effects on water uptake and drying rates of peanut seeds from genotypes resistant and susceptible to invasion by Aspergillus flavus. Agron. J., 68: 661-665.

Ketring, D.L. and Morgan, P.W. 1970. Physiology of oil seeds: I. Regulation of dormancy in Virginia-type peanut seeds. Plant Physiol., 45:268-273.

Ketring, D.L. and Morgan, P.W. 1971. Ethylene as a component of emanations from germinating peanut seeds and its effect on dormant Virginia type seeds. Plant Physiol., 44: 326-330.

Krapovickas, A. and W.C. Gregory. 1994. Taxonomy of the genus Arachis (Leguminosae). Bonplandia., 8: 181-186.

Pandya, R.B. and V.J. Patel. 1986. Dormancy in kernels of Spanish and Virginia bunch varieties of groundnut. J. Oilseeds Res., 3(1): 19-27.

Presley, J.T.1958. Relationship of protoplastpermeability to cotton seed viability and predisposition to seedling disease. Pl. Dis. Reporter., 42(7): 582

Shibuya, T. 1993. Studies on the non germinating seed of peanut (Arachis hypogea L.). Farmosan Agri. Res., 305: 67-75.

Takayanagi, K. and J. F. Harrington. 1971. Enhancement of germination rate of aged seeds by ethylene. Plant Physiol., 47: 521-524

Tang, Y., Keliang, Yin, Z., and Jun, T. 2019. DormancyBreakingandGerminationRequirementsforSeeds of Sorbusalnifolia(Siebold\&Zucc.)K.Koch(Rosaceae), a Mesic ForestTree with High Ornamental Potential. Forests., 10: 3-12.

Vaish, C. P., Singh, C.B., Katiyar, R. P. and Katiyar, P. K. (1991-1994). Dormancy studies in groundnut (Arachis hypogaea L.). Farm Sci. J., 69: 88-90.

Wadia, K. D. R, R. C. Rao, Nageswara and J. H. William, 1987. An improved method for identification of dormant sequentially branched progenies from populations derived from crosses between nondormant (subspecies fastigiata) and dormant (subspecies hypogaea) groundnut (Arachis hypogaea L.). Oléagineux, 42: 275-82.

$107|4-6| 135$ 